Article

\title{
Landscape as a Potential Key Concept in Urban Environmental Planning: The Case of Poland
}

\author{
Aleksandra Sas-Bojarska \\ Department of Urban and Regional Planning, Faculty of Architecture, Gdańsk University of Technology, Poland; \\ E-Mail: asasbo@pg.edu.pl
}

Submitted: 21 January 2021 | Accepted: 20 May 2021 | Published: 19 August 2021

\begin{abstract}
Rapid urban development increases the consumption of materials, energy, and water, resulting in an overproduction of waste and emissions. These cause many environmental threats, such as ozone layer depletion and rain acidification, leading to climate change. Therefore, the question arises on how to improve the effectiveness of tools that strengthen environmental protection. This discursive article presents an approach stressing the role of landscape in environmental protection in Poland. It indicates that landscape protection is an ecological, not just an aesthetic activity, as it is often considered in Poland. The landscape reflects all changes occurring in individual elements of the environment resulting from urban development. Through landscape transformations, one can track the growth and accumulation of adverse effects in the chain of environmental changes. Knowledge regarding the dynamics and scope of these transformations can improve ecological design and technologies. Therefore, the landscape condition should be treated as an indicator of sustainable development. If so, one could hypothesise that effective landscape protection contributes to minimising environmental and climate changes. The relationships between the landscape and environmental/climate threats discussed in this article prompt combining some tools related to these threats, which may ensure both effective landscape protection and sustainable development, leading to reduced climate change. The possibilities and benefits of integrating these tools are presented here as well. General considerations are supplemented with references to the situation in Poland to support the need for implementing a more policy-oriented and interdisciplinary approach to landscape protection.
\end{abstract}

\section{Keywords}

climate change; combining tools; environmental impacts; landscape protection; Poland; urban development

Issue

This article is part of the issue "Smart Urban Governance for Climate Change Adaptation" edited by Thomas Thaler (University of Natural Resources and Life Sciences, Austria), Patrick Witte (Utrecht University, The Netherlands), Thomas Hartmann (TU Dortmund University, Germany) and Stan Geertman (Utrecht University, The Netherlands).

(C) 2021 by the author; licensee Cogitatio (Lisbon, Portugal). This article is licensed under a Creative Commons Attribution 4.0 International License (CC BY).

\section{Introduction}

The sustainable design of urban structures is related to many factors. Among them, the energy aspect (zeroenergy buildings, energy efficiency), strongly associated with preventing the depletion of natural resources and the greenhouse effect, is currently one of the most important issues. Other factors include zero-waste development, saving materials, water and land as nonrenewable goods, and recycling. Numerous procedures are used to solve sustainable design problems: strate- gic environmental assessment (SEA) and environmental impact assessment (EIA), including landscape and visual impact assessment (LVIA), together forming an environmental assessment (EA) system; life cycle assessment (LCA); material flow analysis (MFA); and many more. They all strive to support the design and decisionmaking process in terms of reducing adverse environmental effects. Their use is especially true for the dramatic climate change and an urgent need to stop it. The Polish situation serves as an example of serious environmental and landscape threats resulting from 
excessive investment pressure and a weak legal system of environmental protection, leading to enormous climate change in some regions.

If we consider saving energy, minimising the use of resources, and limiting the amount of waste and supporting environmental protection crucial to pro-ecological planning, it is equally legitimate to state that landscape protection should also be included in it. Although it does not bring measurable and direct effects, it may be considered a sustainable development indicator. Increasing investment pressure and excessive natural resource consumption may cause various changes to individual elements of the environment and the environment as a system, leading to noticeable impacts on the landscape, sometimes shifted in time and space, e.g., desertification, flooding, and changes in vegetation.

The author attempts to answer the questions of why landscape degradation occurs, how it is related to climate change, how to minimise, reduce, or prevent it, and what is the role of landscape in environmental protection, emphasising that the lack of a broad, integrated approach to landscape in investment processes is a symptom of a fragmentary treatment of the environment which results in a weakening of its protection and consequently landscape degradation and ultimately climate change. The aim is to open a discussion at a local (Polish) and international scale on enhancing landscape protection by combining existing tools in a holistic approach.

Several methods have been employed to highlight mentioned problems: literature studies; critical review of existing tools for preventing environmental threats; analysis of Poland's planning context; formulating new hypotheses about combining presented tools; diagrammatic representation of such integration; review of EIA reports; and outlining the directions for future research. In summary, a kind of "abductive" approach is presented to discover new relationships and connections, aiming to develop a theory of environmental and landscape protection (for more on different research approaches see Dubois \& Gadde, 2002).

In Section 2, arguments and tools for applying a landscape approach in environmental planning are given, taking current planning in Poland as an example of this need. In Section 3, several tools for landscape-based planning are presented. Prospects and potentials for integrating these tools in practical planning are the topic of Section 4, followed by Section 5, where the landscape approach to environmental planning is illustrated by systematic reference to the Polish planning situation, including a reflection on the need for further research. In the final section (Conclusions), the arguments favouring a landscape approach in planning for the environment and reducing climate change are summarised.

\section{Landscape and Climate Changes: Relations}

The relationship between landscape and climate changes is not obvious. However, understanding the nature of the landscape and the cause-and-effect chain leading to landscape changes can help understand how climate changes are linked to landscape degradation.

\subsection{The Essence of the Landscape}

According to the European Landscape Convention (Council of Europe, 2000, p. 2), the landscape is "an area, as perceived by people, whose character is the result of the action and interaction of natural and/or human factors." This definition emphasises landscape dynamics and its variability resulting from the interaction between natural and anthropogenic factors. A similar understanding of landscape was presented in connection with the emergence of the EA system in Europe:

Landscape is the result of interdependencies between physical and biological elements and cultural heritage. It includes not only the physical features of terrain and land cover, but also the way these features are perceived, and the value that people give to space. (Department of the Environment, Planning Research Programme, 1995, p. 107)

The landscape covers all physical elements of natural and anthropogenic origins, created not only by physical structures but also by the relations between them and immaterial assets.

\subsection{Landscape and Climate Changes: Effects of Environmental Damage}

Inextricably linked to urban development, every architecture and engineering object needs to be erected, operated, and maintained. The final stage is demolition and material recycling or storage. All of these phases cause material and energy flows. These flows are discharged to valuable products, such as housing estates. However, at some stages of products' lifetime, they become waste or are emitted as pollutants into the environment ( $\mathrm{Li}$ et al., 2016). Therefore, they directly influence the environment. Finally, they accelerate climate change and have different impacts on the landscape.

New objects have a different character, scale and layout, shape, dimensions and textures; occupy different spaces; and are built of various materials. Some emit noise, lighting, gases, dust, water vapour, sewage, and solid waste, and others emit heat, radiation, and vibrations, causing different environmental effects at various stages of their life cycle (construction, functioning, liquidation).

The production of building materials requires the extraction of natural resources and their transport and processing, which often results in landscape destruction?directly or indirectly?through the pollution of the atmosphere. Moreover, all of these activities demand a significant amount of energy, the production of which leads directly to climate change and landscape impacts, 
such as opencast lignite mines or air pollination from coal storage sites.

During the construction stage, activities changing the environment, landscape, and climate are in progress. For example, construction equipment causes noise and atmospheric emissions. As a result, there is a deterioration in air quality and dust deposition on plants and objects, which negatively influence the landscape. Some changes, such as tree felling, can be repaired, e.g., with new plantings. We call these effects reversible. However, sometimes the change is irreversible, e.g., changes in terrain, separation of the unity of natural systems or landscape systems, breaking aquifers, or the emergence of new engineering facilities - all of them negatively change the landscape.

Other types of environmental effects occur during the operation time, the longest stage of the object's life. The investment may cause noise and exhaust emissions, an increase in air pollution, sewage discharge, constant lighting, etc. It may impact the physical and mental health of exposed residents. After some time, renovations are necessary to extend the operation stage of the facility. Noise and emissions into the atmosphere may occur again, changing the landscape and the climate.

At the end comes the demolition of the facility, removal of materials, their reuse, recycling, and storage. Demolition works and transport of waste cause emission of noise, vibration, and dust, increasing air pollution. In addition, waste must be stored somewhere and thus takes up space, which is a non-renewable resource. These effects significantly reduce the quality of the landscape. And what is more dangerous, they lead to global climate change, which may cause global landscape destruction in a negative feedback loop, such as drastic devastation of regional ecosystems caused by drought.

The effects appearing in the environment and consequently in the landscape and climate can be classified by stages of the investment's lifetime, the scale of the object as well as the scale of changes, the reversibility of these changes, their durability or variability, duration, spatial extent, the possibilities of minimising them, and finally their source, which is crucial in avoiding and mitigating them. This diversity requires a comprehensive approach to studying and reducing them. Consequently, the disconnected use of specific prognostic methods does not bring satisfactory results, which can be seen in the scale of environmental and landscape damage and climate change.

\subsection{Landscape Protection: Circumstances and Needs in Poland}

The principles of landscape-related policies in Poland are outlined very generally in the National Development Strategy 2020 (Polish Council of Ministers, 2012) and more specific in the strategies of voivodeships (regions), districts, and communes concerning development. The National Development Strategy underlines the need to protect resources and environmental diversity and extrimily shortly highlights aspects of protecting the landscape. In addition, legal provisions regarding the landscape are included in regulations and planning documents at various levels: the concept of spatial development of the country, voivodeship spatial development plans, metropolitan plans, studies of conditions and directions of the spatial development of communes, local land use plans, and the provisions specifying the functioning of the EA system in Poland.

Despite the existence of extensive legal regulations concerning landscape protection in Poland, there are numerous reasons for landscape devastation:

- Formal and legal: defects, ineffectiveness, and lack of precision of legal regulations (Böhm, 2008; Giedych \& Szumański, 2003; Górka, 2016); no integration of issues related to spatial planning, the environment, monuments, and landscape with socio-economic planning (Szulczewska, 2002); weak competencies of administrative services in the field of landscape protection; general nature of the provisions of laws and regulations regarding landscape (Chmielewski, 2013); individual approach to different elements of the environment by the law; inconsistent landscape policy (Lipińska, 2011).

- Economic and social: dynamics of new development; low level of space management; imitation of foreign patterns (Lipińska, 2011); misunderstanding of the idea of spatial planning in market economy conditions (Jędraszko, 2005; Świetlik, 2003); low level of public debate; short-term approach; omission of quality criteria in administrative procedures; marginalisation of the landscape; low landscape awareness (Górka, 2016).

- Insufficient use of existing tools in the decisionmaking processes in spatial/urban planning due to: organisational shortcomings of the system of environmental protection; underinvestment of this system; administrative staff competency shortages originating from the lack of a coherent system of teaching these tools at universities, among others (see Section 4.2).

Landscape protection is a broad and still topical issue in Poland because the landscape is frequently underestimated. In common opinion, it does not refer to sustainable development but only to its aesthetic aspect. The variety of "landscape" definitions and interpretations is not only a Polish issue. The landscape concept has multiple meanings, scales, and applications in a general and national context, e.g., the Swedish case described by Sandström and Hedfors (2018). Meanwhile, the previous section shows that both landscape and climate changes stem from environmental damage. Therefore, there is a need to implement methods that may support spatial planning because spatial planning is not effective enough to protect the environment, climate, and landscape. 


\section{Smart Tools Reducing Environmental, Landscape, and Climate Changes}

The methods dedicated to landscape protection have been selected for further analysis. These are SEA, EIA, LVIA, and complementary tools, such as LCA and MFA, which together play an essential role in sustainable planning (Table 1). Combined, they check a multitude of different effects in the entire chain of environmental transformation resulting from development. Thereby, they relate to the landscape that reflects the accumulation of these changes.
SEA, EIA, LVIA, LCA, and MFA enable environmental threats, potentially caused by increasing development, to be minimised, but their goals and scope are different. Some of them are procedure-oriented and refer directly to environmental and landscape protection (SEA, EIA, LVIA), helping to make a balanced decision concerning future development. In contrast, others (LCA, MFA) support them as analytical tools focused on technical issues (see Supplementary File). But none of them-when treated separately-is sufficient to stop the increasing destruction of the environment and consequently protect landscape and climate.

Table 1. Tools reducing environmental and climate changes and their functions, advantages, and relationship to landscape.

\begin{tabular}{|c|c|c|}
\hline Tool & Function & Advantages \\
\hline SEA & $\begin{array}{l}\text { Delivering objective and detailed } \\
\text { information on the project of } \\
\text { strategic documents (policies, } \\
\text { plans, programmes), } \\
\text { environmental goals, endangered } \\
\text { environment, potential } \\
\text { environmental effects, mitigation } \\
\text { measures and recommendations; } \\
\text { mitigating environmental impacts } \\
\text { at policy/planning level }\end{array}$ & $\begin{array}{l}\text { Allowing open decision-making } \\
\text { due to public participation; } \\
\text { supporting and influencing } \\
\text { policies, plans and programmes in } \\
\text { sustainable development; } \\
\text { improving EIA through considering } \\
\text { economic, ecological and social } \\
\text { aspects at a higher level; wider } \\
\text { than in EIA scope of effects; } \\
\text { showing alternative possibilities of } \\
\text { achieving goals }\end{array}$ \\
\hline
\end{tabular}

EIA Delivering objective and detailed information on the planned harmful activity, endangered environmental resources and values, potential environmental impacts and the possibilities of their minimising; considering alternatives; mitigating environmental impacts at the local level

LVIA Assessing and mitigating landscape impacts at the local/regional level within EIA; presenting visual problems in a way understandable for recipients

LCA Assessing environmental impacts connected with products and activities based on analysing product lifetime; selection of environmentally friendly materials and technologies

MFA Identification of inefficiencies in the use of resources; prediction of the future natural resources and energy demand and possible environmental impacts of a development
Allowing open decision-making due to public participation; enabling choices best for the environment; enabling balanced decisions; environmental protection; sustainable development; promoting ecological education

Creating landscape framework for governance arrangements and planning policies in terms of spatial planning

Enhancing EIA at different stages; minimising waste production and resource consumption; enabling energy efficiency; reducing greenhouse gas emissions

Studying and limiting the demand for materials and energy arising from development; supporting decision-making related to environmental, resource- and water-quality management
Relationship to landscape

Very general relationship to landscape and landscape changes resulting from project implementation; general guidance on the landscape at the national, regional or commune level; general references to other documents related to landscape

The landscape is one of many issues; direct or indirect relationship to landscape; general or specific guidance related to the landscape at different scales

Directly related to the landscape; specific and detailed guidance related to landscape shaping and protecting

Indirectly related to the landscape-only by combining with other tools; no direct guidance related to the landscape

Indirectly related to the landscape-only by combining with other tools; no direct guidance related to the landscape

Note: Based on the information available in the Supplementary File. 


\section{Integration of Tools: Perspectives and Possibilities}

At each stage of the investment lifetime, the potential environmental effects resulting from implementing the concepts, strategies, policies, plans, spatial development plans, and projects should be examined using SEA, EIA, LVIA, LCA, and MFA. But they are not always used according to their role and capabilities. They are usually not treated as a complementary system but used individually at various stages of the product's lifetime. However, they have the potential to be used comprehensively and systemically to minimise environmental damage and consequently climate change.

\subsection{Benefits of SEA, EIA, LVIA, LCA, and MFA Integration}

Due to the complexity of the problems to be solved, researchers emphasise the need to integrate various methods related to decision-making processes connected with development. The merits of combining MFA and LCA have been proven to help evaluate and implement sustainable development and support decisionmaking (Brunner \& Rechberger, 2004; Guaita et al., 2018; Westin et al., 2019), and predict material flows and environmental benefits of the recycling chain, such as natural resource savings (de Meester et al., 2019). Consolidation of LCA and MFA may improve effective decision-making, leading to a halt in negative trends and introducing environmentally friendly technologies. LCA and MFA help understand the importance of reducing raw material consumption, energy use, quantities of waste, and $\mathrm{CO}_{2}$ emissions by recycling, eco-technologies and prolonging the lifetime of buildings. Despite this, in some countries, there is a lack of connection between LCA and MFA. Although MFA can measure the material flows in and out of the system, it cannot assess the environmental consequences of the emission of this flow, which can be achieved using LCA (Guaita et al., 2018).

According to some researchers, the role of LCA may be much broader. Among few other tools, LCA may enhance the SEA by identifying and modelling environmental changes (Finnveden et al., 2003). The assessment of environmental impacts in SEA is generally based on qualitative descriptions and general statements, lacking analytical methods (Geneletti, 2015). Therefore, combining SEA with LCA and MFA may enrich quantitative research, increasing the effectiveness of environmental prognoses.

LCA can enhance EIA because regional and global effects can be considered thanks to LCA, in contrast to EIA (Manuinova et al., 2009). The use of LCA during a few critical stages of EIA may provide broader knowledge on the environmental effects of planned activities (considering the global aspects) compared to using EIA alone (Larrey-Lassalle et al., 2017). Scoping (impact identification), environmental impact assessment and indicating mitigation measures are crucial stages in EIA. At the scoping stage, LCA may help in the quantitative com- parison of alternatives. During the impact assessment, LCA may provide quality assessment connected with the life cycle. Methods used under LCA may apply to EIA to increase the accuracy and detail of EAs (Manuinova et al., 2009). Companies rarely use LCA as a costly and timeconsuming method, so simplified EA methods are recommended (Zafeirakopoulos \& Genevois, 2015). The combination of EIA and LCA can be used for this purpose, focusing only on the most significant potential environmental impacts.

The new proposal for the advanced integration of EIA and LCA systems is based on practical research. Until now, only theoretical considerations on this topic could be found in the literature, with EIA and LCA systems combined only in a fragmentary way. The described approach aims to use all of the benefits of LCA in the comprehensive procedure, indicating specific EIA stages to use LCA and proposing a recommended methodology for this integration. It has been proven that in most EIA procedures not supported by LCA, the environmental effects of all technologies are not studied, and indirect and off-site impacts are not included. It has been stated that using LCA within EIA could help to analyse global effects, such as resource and ozone depletionand climate change (Larrey-Lassalle et al., 2017).

The benefits of supplementing EIA with LCA relate to Directive 2014/52/EU, which underlines the need to consider the broader catalogue of environmental effects associated with the depletion of natural resources, climate change, energy, and human health (Larrey-Lassalle et al., 2017). LCA allows the evaluation of more holistic environmental problems than EIA. Still, on the other hand, it does not apply to local conditions and interference, which is the function of EIA (Larrey-Lassalle et al., 2017). As a support tool for EIA, MFA has been described using the example of chosen case studies (Brunner \& Rechberger, 2004).

Comprehensive analysis of many tools for land use impact assessment, including among others MFA, LCA, EIA, SEA, and ecological footprint (EF) described in 60 articles (chosen from 187), showed their most common combination: LCA and MFA-10 examples; LCA and $E F-10 ; M F A$ and EF-7; EIA and EF-2; EIA and MFA-1 (Perminova et al., 2016). But no combination of all these tools has been found in this review. Perminova et al. (2016) recommended combining various methods and different aspects of each method, but neither the use of LVIA procedure nor the references to the landscape were suggested.

\subsection{The Need for SEA, EIA, LVIA, LCA, and MFA Integration in Poland}

Although SEA, EIA, LVIA, LCA, and MFA are known and used in Poland, their functioning is not related to eachother. The level of implementation of the idea of a circular economy, which should cover all lifetime cycles, is still unsatisfactory in Poland (Polish Council of Ministers, 
2019). Legal regulations do not require combining LCA and MFA with EA. They are used separately. The information obtained during EA studies is not connected with the material flow; therefore, data concerning construction materials or energy consumption during its whole lifetime are not included.

The EA system is not consistent either. SEAs of strategies and planning documents often strongly depend on political goals; therefore, environmental protection plays a minor role. SEA and EIA do not create a complementary system. Various types of strategic documents or planned activities and the accompanying SEA, EIA, and LVIA are subject to the opinion and approval of many institutions at various government and local administration levels, which results in ambiguities in competencies and responsibilities. Moreover, governmental and local administrations are often guided by different priorities in matters of environmental protection, which makes it difficult to use the potential of tools to make balanced administrative decisions. Only EIAs of great controversial activities are bound with SEA.

In general, SEA in Poland at the lowest levels (concerning local land use plans and studies of conditions and directions of the spatial development of communes) is rarely used for the management of urban areas in the context of spatial planning. The guidances from such SEAs are usually very general. They contain recommendations to be detailed only at the next stageassessments of planned activities during the EIA procedures. Moreover, the most commonly used SEAs in Poland concern local land use plans, which are smallscale and fragmentary and make it impossible to assess cumulative, long-term and secondary impacts. Avoiding them is possible only at the higher levels of environmental planning, i.e., the stage of creating regional plans, policies, and programmes.

The situation is different for SEA of strategic documents, e.g., the National Road Construction Program (Polish Council of Ministers, 2015) or Voivodeship Development Strategies, because their implementation in the future will involve possible co-financing from EU funds. In such cases, before the grant is awarded, it will be checked if a specific activity has been included in the strategic document together with the SEA. That is why SEAs are and will be so crucial for decision-makers and beneficiaries applying for funding. Furthermore, recommendations from SEAs are essential for administrative bodies adopting strategic documents at the national and regional level. The example from the Pomeranian Voivodeship is perfect. SEA related to the project of the Pomeranian Voivodeship Development Strategy 2030 (Pomeranian Voivodeship, 2020), contains, e.g., mitigation measures and recommendations concerning landscape and cultural landscape. Under the influence of the recommendations, the project of the Pomeranian Voivodeship Development Strategy 2030 (Pomeranian Voivodeship, 2021), was significantly revised. Following public participation consultations,
Pomeranian Voivodeship Development Strategy 2030 was then, along with SEA, agreed with all relevant institutions almost without any reservations, which means that, in this case, SEA significantly influenced the arrangements for the management of the voivodeship in the context of spatial planning.

The EIA procedure in Poland is carried out at an early stage of investment planning, when neither the investor nor experts have sufficient knowledge about all potential environmental effects. Therefore, the EIA reports are somewhat general, making it impossible to mitigate adverse effects, including landscape effects, adequately. Usually, the analysis of impacts on various environmental elements is carried out independently by the experts. Consequently, the synergistic and cumulative effects are not taken into account. In addition, investors sometimes consider EIA a burdensome but necessary formality that can be completed by operating in the grey area of regulations.

Landscape in EIA, dominated by technical and ecological specialities, is considered the least important element of the environment. The landscape is sometimes regarded only in geographical or aesthetic terms. This approach stems from the definition of landscape in Polish law (Sejm, 2015), which does not underline relationships and interactions of natural and cultural factors. Therefore, the landscape is seen as an isolated element of the environment, directly related to the visual aspects, without showing a clear correlation with effects occurring in other elements of the environment (Lipińska, 2011; Sas-Bojarska, 2017), which limits the effectiveness of mitigation measures. As a result, the potential of LVIA is used to a small extent. It is not the landscape values that are an argument against the implementation of controversial activities but the geographic and natural aspects (especially the Natura 2000, which concerns the most valuable and threatened species and habitats listed in the Birds Directive and the Habitats Directive) and economic and social aspects. Supporting tools, such as LCA and MFA, are practically not considered when making planning decisions. All this undermines landscape protection.

All of the above shortcomings prevent the potential of the described tools from being fully used, which results in a lack of coherent planning of sustainable development in Poland, especially concerning landscape and climate changes.

\subsection{Conclusions From the Integration}

SEA, EIA, LVIA, LCA, and MFA have great potential for the implementation of sustainable development, although their goals, methodologies, scope, and merits differ. In protecting the environment, they can also preserve its general image, i.e., the landscape. Large-scale activities, especially those consuming a tremendous amount of energy and water, and causing emissions and waste, require interacting tools. 
The benefits briefly outlined indicate that SEA, EIA, LVIA, LCA, and MFA should be used together to assess environmental impacts in terms of various stages of the lifecycle, spatial scope (local, regional, global), magnitude, and significance (the shortcomings and need to broaden the scope of impact significance are underlined in Lawrence, 2007). Only then can these impacts be effectively limited. Recommendations regarding development directions, related threats, and possibilities of mitigating them resulting from interacting procedures should be used not only in assessing a specific investment but also more broadly when creating spatial policy principles. Emphasising the importance of the landscape issues both at wider and local scales can contribute to greater involvement in environmental actions at the local level, which is the most effective. The potential of these combined tools indicates that in-depth research should be undertaken to strengthen bridging ideas and improve the effectiveness in environmental, landscape and climate protection, which is a crucial issue, especially in Poland.

\section{Towards Sustainability: Combining Tools in Landscape Impact Assessment}

This new approach to increasing the effectiveness of landscape protection is based on combining a few existing methods (SEA, EIA, LVIA, LCA and MFA), which have only been used separately in Poland until now. This improvement is based on the notion that only the enhancement of the role of the landscape in investment processes through simultaneous use of different tools related to the landscape can enable adequate prediction and minimisation of changes in the landscape and environment and consequently mitigate climate change.

\subsection{Landscape: The Image of Relationships}

The suggested approach of considering all interrelations between individual elements of the environment, and the effects appearing in them, becomes possible thanks to various methods supporting landscape impact assessment. Only cooperation of the experts from many fields can ensure comprehensive prediction of landscape changes and consequently its successful protection. Figure 1 shows the multitude of dependencies to be considered and, although difficult to analyse, offers a perspective on the complexity of the subject matter as opposed to the current, often overly simplistic, practice based on separate studies in specific elements of the environment.

The landscape is treated here not only as a separate component of the environment, but it becomes the synthesis of all environmental research because it is the final recipient of the accumulation of effects appearing in subsequent elements of the environment and the environment as a whole. It reflects both direct changes caused by the implementation and functioning of the activity and indirect, cumulative and synergistic effects and dynamic interactions, emerging at various stages of the investment lifetime. Such an approach refers to the European Landscape Convention presenting the

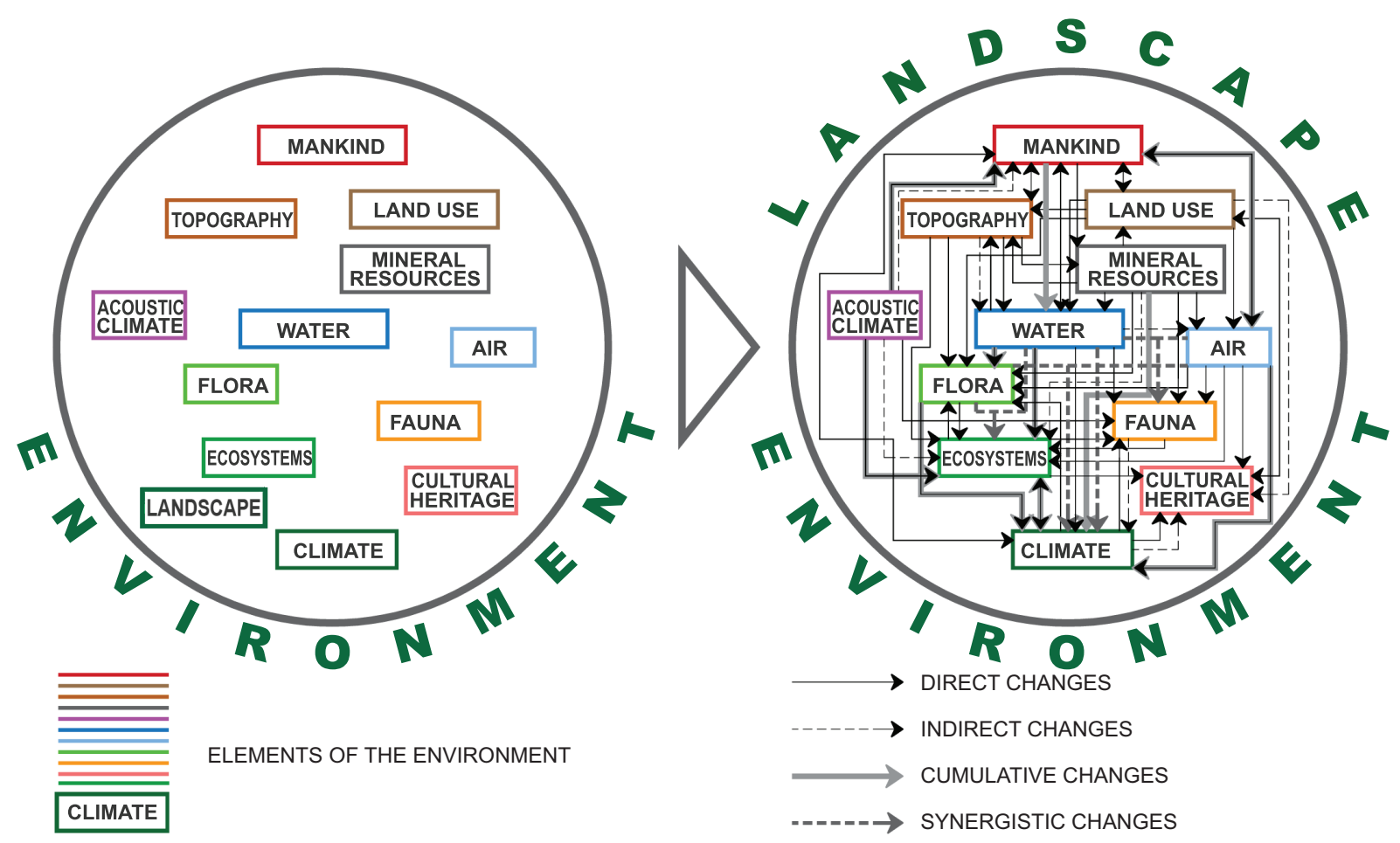

Figure 1. Linking studies in EIA. Current practice in Poland: Landscape as a separated element of the environment. Recommended approach: Landscape as the indicator of changes in different elements of the environment. 
landscape, according to Sandström and Hedfors (2018), as a general matrix of the planning arena of different interacting systems, bridging sectorial initiatives. In sum, the landscape is considered a medium connecting all prognoses, a reference point for other environmental studies. Thus, the effectiveness of predictions of landscape change increases, enhancing the possibilities of mitigating adverse impacts, which is imperative in light of the growing social role of the landscape. Fortin and Gagnon (2006) underline the importance of considering the values and expectations of local residents and actors affected by the project. Taking into account the landscape meanings may, in their opinion, enrich formal practices associated with EIA and regional planning. A great number of mandatory and voluntary integration tools promote more integrated policies, planning, and practices (such as EIAs and SEAs). Still, their implementation is usually insufficient, so further research is recommended (Runhaar, 2016). The presented approach may be regarded as a modest contribution towards this recommendation, not only in Poland.

\subsection{Introducing the Landscape Approach to the Polish Environmental Planning Practice}

Because the current practice of environmental studies in Poland is based on the separate use of different methods, one could conclude that some procedures, such as SEA, EIA, LVIA, LCA and MFA, should be integrated (Figure 2).

When used together, these methods make it possible to improve the LVIA effectiveness, thereby increasing the effectiveness of landscape protection in spatial management and development. This is recommended especially in complex cases, where the interrelationships between various effects in specific elements of the environment make it difficult to forecast changes in the landscape. Moreover, it somewhat replaces the lack of standards in assessing the significance of landscape impacts. However, standardisation, perceived as beneficial in EIA, is still a challenging task (Fonseca et al., 2020).
In the recommended approach, the landscape becomes a leading aspect in EIA/LVIA, supported by SEA, LCA, and MFA, and can thus have a significant impact on planning decisions. Obligatory considerations of the landscape when forecasting any environmental effects require integrating information from various fields and studies and assessing cause-effect relationships, leading to cumulative and synergistic effects. This approach increases the effectiveness of forecasting changes in the environment as a complex system, reduces the uncertainties associated with prognosis, and enables the identification of irreversible and unacceptable effects. There is a positive feedback loop between environmental protection and landscape protection-when the environment is protected effectively, the landscape is protected effectively and vice versa. Such complementarity of protection should influence the current governance arrangements in terms of urban and spatial planning. As a consequence, minimising environmental and landscape impacts will become more effective, thus reducing climate change.

The key challenge with practically implementing the recommendation of combining SEA, EIA, LVIA, LCA, and MFA is incentivising the stakeholders to follow this framework, disregarding it might be time-consuming and economically inefficient for the investors. Furthermore, the idea for integrating presented tools is so far more hypothetical than actually concrete and measurable for evaluation. Therefore, this hypothesis requires confirmation in detailed studies. Without them, it cannot be verified. Referring to the conclusions from Section 4.1, a proposed procedure for examining EIA reports concerning the landscape is presented below. The reference to the landscape is considered crucial because the landscape impact prediction, at least in Poland, is still not connected well enough with other studies. The difficulties in finding useful tools for analysing effects on landscapes in SEA have been recognised (Finnveden et al., 2003). EIA/LVIA also require finding supporting tools. LCA and MFA could fill this gap.

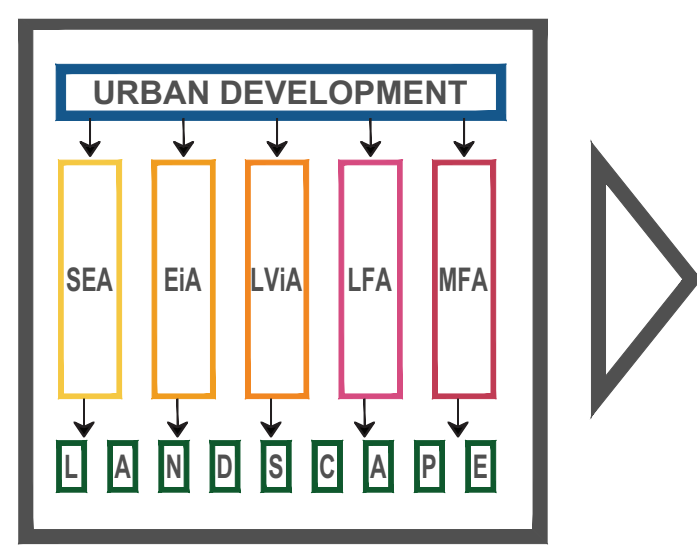

CURRENT PRACTICE — SEPARATE STUDIES

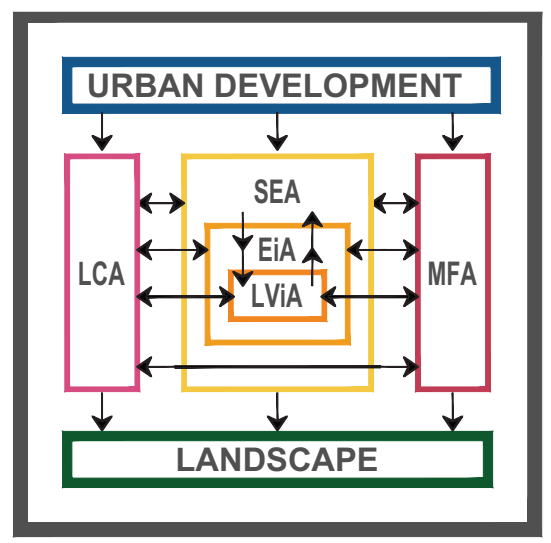

NEW APPROACH — INTEGRATED STUDIES

Figure 2. Integration of tools: The recommended holistic approach to landscape protection. 


\subsection{Further Research}

The proposed study intends to show if and to what extent different tools are practically combined in EIA procedures and indicate the impact of such combinations on the environment and landscape. The methodology of further research presented below is universal, but its creation relates to Polish conditions. A review of 79 randomly selected EIA reports from various years (1993-2018), related to 11 voivodeships in Poland and concerning controversial investments of different character (large-scale objects, linear infrastructural structures, and large-area activities), showed that none referred to LCA or MFA. This finding indicates that the integration of these procedures is not practised in Poland.

Because it was found that conducting an EIA requires additional tools, and all studies should relate to the landscape, the recommended course of action is shown below.

The proposed study aims to enable the assessment and validation of the new approach by answering the following questions after analysing a sample of EIA reports and related procedures:

The first phase-checking the content of EIA reports:

- Is there a reference to SEA in the EIA report? Are any conclusions from SEA related to landscape? Are they included in the EIA report?

- Is there a reference to landscape in the EIA report? Was LVIA performed? What percentage of the content relates to the landscape? Did the predicted landscape threat influence the conclusions of the report?

- Is there a reference to LCA/MFA in the report? If so, is there a reference to landscape in the LCA/MFA chapter? What percentage of the content does it take up? Did it affect the conclusions?

- What is the difference between EIA reports without LCA/MFA reference and reports with such reference in terms of the landscape? A comparison should be made.

- If there is no direct reference to the landscape in LCA/MFA chapters, a forecast must be made of what landscape changes will occur (such a study should be carried out by an architect/landscape architect based on LCA/MFA studies).

The second phase-analysis of the results of environmental audits:

- Was the monitoring and/or post-implementation environmental audit carried out? Did the audit somehow relate to the landscape? Did it show any damage to the landscape?

- What was the cause of landscape damage? Which environmental element's destruction influenced the changes in the landscape?

- What was the nature of the destruction of the landscape? Were these effects long-term, irre- versible, significant, mitigable, unacceptable? Did they interfere with tourist activity? Did they cause social controversy?

- Would carrying out an LCA/MFA under the EIA indicate the possibility of landscape degradation? Any such relationship should be indicated.

- What are the actual changes in the landscape when conducting EIA using LCA/MFA? And without them? A comparison should be made.

It should be noted that the second phase may pose many difficulties because "the most critical condition seems to be the monitoring of how tools are used and what they achieve" (Runhaar, 2016, p. 7).

Recommended research should show if and to what extent it is possible to effectively predict landscape changes when combining SEA, EIA, LVIA, LCA and MFA. This methodology is intended to enable specific studies to confirm the presented hypothesis and evaluate the effectiveness of the proposed approach.

\section{Conclusions}

The world is facing rapidly growing urban development and industrialisation, causing irreversible environmental threats and leading to the most dangerous of all, i.e., climate change. That is why urgent actions are needed to stop these trends. In the context of the increasing complexity of socio-economic processes and uncertainty of their forecasting, it seems that one of the most effective tools for implementing sustainable development is the EA system applied to all levels of human activity (local, regional, global), including various spheresnatural, socio-cultural, visual, and technical. It enables a multi-criteria assessment of planning/design solutions and the choice of better alternatives for the environment. However, it is only in cooperation with instruments such as LCA and MFA that an opportunity to prevent damage to the environment at every stage of the lifetime of planned activities can be created. The key message of this article is that landscape protection in investment processes is part of pro-ecological and not just aesthetic activities because the effects on the landscape arising from the development reflect the changes in all elements of the environment. Therefore, understanding the relationships between the environmental effects and the landscape can contribute, especially in Poland, to improving the use of tools supporting spatial planning, such as EA, LCA, and MFA.

In Poland, there are well-developed tools for protecting the environment and landscape (e.g., the EA system), but their functioning is not satisfactory. The use of tools such as SEA, EIA, LVIA, LCA, and MFA depends largely on the efficiency of the environmental management system. This system in Poland is poorly organised and ineffective. Therefore, the potential of the described tools is not fully unlocked, aggravating spatial chaos and environmental and landscape degradation. Moreover, 
issues related to the landscape have a low rank in local, regional, and national administration policies and activities. Landscape protection tends to fail when confronted with social or economic arguments. All this leads to the progressive degradation of the landscape. Therefore, it is necessary to strengthen the role of landscape criteria in decision-making processes. There is an opportunity to link the landscape problems more closely with the environmental and climate issues, which have already gained significant importance in the world. This can be achieved by combining the described tools to better forecast the unfavourable effects of development processes. Such an approach shows that the protection of the landscape, i.e., the synthesis of the environment, can at the same time positively influence the reduction of climate change. Further detailed research, necessary to confirm this hypothesis, is yet to be adequately tested in practice.

\section{Acknowledgments}

The author is grateful for the exceptionally valuable comments from the reviewers and editors. Furthermore, the author would like to thank M. Kiejzik-Głowińska of EKO-PERSPEKTYWA for collecting EIA reports for this study and her comments; M. Bednarska, the author of SEA related to the Project of the Pomeranian Voivodeship Development Strategy 2030 of the Pomeranian Regional Planning Office; and A. Tyszecki, the EA consultant, for their constructive remarks concerning the Polish EA system.

\section{Conflict of Interests}

The author declares no conflict of interests.

\section{Supplementary Material}

Supplementary material for this article is available online in the format provided by the author (unedited).

\section{References}

Böhm, A. (2008). Skuteczność istniejących w Polsce instrumentów prawnych [The effectiveness of existing legal instruments in Poland]. Czasopismo Techniczne, 1(A), 137-146.

Brunner, P. B., \& Rechberger, H. (2004). Practical handbook of material flow analysis. Lewis Publishers, CRC Press.

Chmielewski, T. J. (2013). Systemy krajobrazowe. Struktura-funkcjonowanie-planowanie [Landscape systems. Structure-functioning-planning]. PWN Scientific Publishing House.

Council of Europe. (2000). European Landscape Convention (European treaty series, No. 176). https://rm. coe.int/1680080621

de Meester, S., Nachtergaele, P., Debaveye, S., Vos, P., \& Dewul, J. (2019). Using material flow analysis and life cycle assessment in decision support: Case study on WEEE valorization in Belgium. Resources, Conservation \& Recycling, 142, 1-9. https://pg.edu.pl/ biblioteka-pg/alfabetycznie

Department of the Environment, Planning Research Programme. (1995). Preparation of environmental statements for planning projects that require environmental assessment: A good practice guide. HMSO Publications Centre.

Dubois, A., \& Gadde, L.-E. (2002). Systematic combining: An abductive approach to case research. Journal of Business Research, 55, 553-560. https://pg.edu.pl/ biblioteka-pg/alfabetycznie

Finnveden, G., Nilsson, M., Johansson, J., Persson, Å., Moberg, Å., \& Carlsson, T. (2003). Strategic environmental assessment methodologiesApplications within the energy sector. Environmental Impact Assessment Review, 23, 91-123. https://pg. edu.pl/biblioteka-pg/alfabetycznie

Fonseca, A., de Brito, L. L., \& Gibson, R. B. (2020). Methodological pluralism in environmental impact prediction and significance evaluation: A case for standardization? Environmental Impact Assessment Review, 80, 1-9. https://pg.edu.pl/biblioteka-pg/ alfabetycznie

Fortin, M., \& Gagnon, C. (2006). Interpreting major industrial landscapes: Social follow-up on meanings, the case of two aluminium smelters, Alcan (Alma, Canada) and Pechiney (Dunkirk, France). Environmental Impact Assessment Review, 26, 725-745. https:// pg.edu.pl/biblioteka-pg/alfabetycznie

Geneletti, D. (2015). Research in strategic environmental assessment needs to better address analytical methods. Journal of Environmental Assessment Policy and Management, 17(1), 1-7. http://dx.doi.org/ 10.1142/S1464333215500143

Giedych, R., \& Szumański, M. (2003). Krajobraz w systemie planowania przestrzennego [Landscape in the spatial planning system]. Urbanista, 7, 18-22.

Górka, A. (2016). Krajobrazowy wymiar ruralistyki [The landscape dimension of ruralism]. Gdańsk University of Technology Publisher.

Guaita, F. G., García, S. G., Villanueva-Rey, P., Moreira, M. T., \& Feijoo, G. (2018). Integrating urban metabolism, material flow analysis and life cycle assessment in the environmental evaluation of Santiago de Compostela. Sustainable Cities and Society, 40, 569-580. https://pg.edu.pl/biblioteka-pg/alfabetycznie

Jędraszko, A. (2005). Zagospodarowanie przestrzenne w Polsce-drogi i bezdroża regulacji ustawowych [Spatial development in Poland-Ways and sideways of statutory regulations]. Union of Metropolises of Polish Cities.

Larrey-Lassalle, P., Catel, L., Roux, P., Rosenbaum, R. K., Lopez-Ferber, M., Junqua, G., \& Loiseau, E. (2017). An innovative implementation of LCA within the EIA procedure: Lessons learned from two wastewater treatment plant case studies. Environmental Impact 
Assessment Review, 63, 95-106. https://pg.edu.pl/ biblioteka-pg/alfabetycznie

Lawrence, D. P. (2007). Impact significance determination-Pushing the boundaries. Environmental Impact Assessment Review, 27, 770-788. https://pg.edu.pl/biblioteka-pg/alfabetycznie

Li, Y., Beeton, R. J. S., Halog, A., \& Sigler, T. (2016). Evaluating urban sustainability potential based on material flow analysis of inputs and outputs: A case study in Jinchang City, China. Resources, Conservation \& Recycling, 110, 87-98. https://pg.edu.pl/bibliotekapg/alfabetycznie

Lipińska, B. (2011). Ochrona dziedzictwa kulturowego. Ujęcie krajobrazowe [Protection of cultural heritage. Landscape perspective]. Gdańsk University of Technology Publisher.

Manuinova, A., Suebsiri, J., \& Wilson, M. (2009). Should life cycle assessment be part of the environmental impact assessment? Case study: EIA of $\mathrm{CO} 2$ capture and storage in Canada. Energy Procedia, 1, 4511-4518. https://pg.edu.pl/biblioteka-pg/ alfabetycznie

Perminova, T., Sirina, N., Laratte, B., Baranovskaya, N., \& Rikhvanov, L. (2016). Methods for land use impact assessment: A review. Environmental Impact Assessment Review, 60, 64-74. https://pg.edu.pl/ biblioteka-pg/alfabetycznie

Polish Council of Ministers. (2012). Strategia Rozwoju Kraju 2020 [National development strategy 2020] (Polish Monitor, item 882, Resolution No. 157 of the Council of Ministers of September 25, 2012).

Polish Council of Ministers. (2015). Program Budowy Dróg Krajowych na lata 2014-2023 (z perspektywq do 2025 r.) [National road construction program for 2014-2023 (with perspective until 2025)]. https://www.gov.pl/web/infrastruktura/programbudowy-drog-krajowych-na-lata-2014-2023-zperspektywa-do-2025-r

Polish Council of Ministers. (2019). Polityka ekologiczna państwa 2030-strategia rozwoju w obszarze środowiska i gospodarki wodnej [National ecological policy 2030-Development strategy in the area of environment and water management].

Pomeranian Voivodeship. (2020). Prognoza oddziaływania na środowisko projektu Strategii Rozwoju Województwa Pomorskiego 2030 [SEA related to the project of the Pomeranian Voivodeship development strategy 2030]. https://strategia2030.pomorskie.eu/ -/konsultacje-projektu-strategii-rozwojuwojewodztwa-pomorskiego-2030-w-ramachstrategicznej-oceny-oddzialywania-na-srodowisko

Pomeranian Voivodeship. (2021). Strategia Rozwoju Województwa Pomorskiego 2030 [Pomeranian Voivodeship development strategy 2030]. https:// strategia2030.pomorskie.eu/-/uzasadnienie-ipodsumowanie-do-strategii-rozwoju-wojewodztwapomorskiego-2030

Runhaar, H. (2016). Tools for integrating environmental objectives into policy and practice: What works where? Environmental Impact Assessment Review, 59, 1-9. https://pg.edu.pl/biblioteka-pg/ alfabetycznie

Sandström, U. G., \& Hedfors, P. (2018). Uses of the word 'landskap' in Swedish municipalities' comprehensive plans: Does the European Landscape Convention require a modified understanding? Land Use Policy, 70, 52-62. https://pg.edu.pl/biblioteka-pg/ alfabetycznie

Sas-Bojarska, A. (2017). Wielkie inwestycje w kontekście zagrożeń i ochrony krajobrazu [Big-scale activities in the context of landscape threats and protection]. Gdańsk University of Technology Publisher.

Sejm. (2015). Ustawa z dnia 24 kwietnia 2015 r. o zmianie niektórych ustaw $w$ zwiqzku ze wzmocnieniem narzędzi ochrony krajobrazu, Dz.U. 2015 poz. 774 [Act of 24 April 2015 on amending certain acts in connection with the strengthening of landscape protection tools, Journal of Laws of 10 June 2015. Art. 774].

Szulczewska, B. (2002). Teoria ekosystemu w koncepcjach rozwoju miast [Ecosystem theory in urban development concepts]. SGGW Publisher.

Świetlik, M. (2003). Planowanie przestrzenne versus ekonomia [Spatial planning versus economics]. Urbanista, 9, 34-38.

Westin, A. L., Kamykova, Y., Rosado, L., Oloveira, F., Laurenti, R., \& Rydberg, T. (2019). Combining material flow analysis with life cycle assessment to identify environmental hotspots of urban consumption. Journal of Cleaner Production, 226, 526-539. https://pg. edu.pl/biblioteka-pg/alfabetycznie

Zafeirakopoulos, I. B., \& Genevois, M. E. (2015). An analytic network process approach for the environmental aspect selection problem-A case study for a hand blender. Environmental Impact Assessment Review, 54, 101-109. https://pg.edu.pl/biblioteka$\mathrm{pg} /$ alfabetycznie

\section{About the Author}

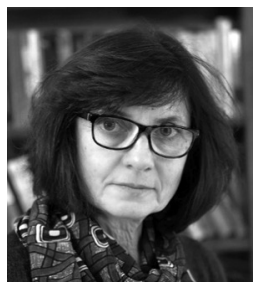

Aleksandra Sas-Bojarska is a Professor at the Department of Urban and Regional Planning, Faculty of Architecture, Gdańsk University of Technology, Poland. Her research efforts focus on sustainable development, revitalisation, landscape protection, EIA in urban planning, and LVIA methodology. She has participated in many EIA procedures concerning large-scale activities in urban and rural areas. In addition, she is an expert of the Pomeranian Voivodship's Commission on Environmental Impact Assessment in Gdańsk, under the Regional Direction of Environmental Protection. 